\title{
(Re)defining the First Mark of Development: Lebanese Feminist Discourse in Al-Raida, 1976-1985
}

\author{
Nicole Khoury
}

To cite this article: Khoury, N. (2018). (Re)defining the First Mark of Development: Lebanese Feminist Discourse in Al-Raida, 1976-1985. Al Raida, 42(2), 86-112. DOI: 10.32380/alrj.v42i2.1743

To link to this article: http://dx.doi.org/10.32380/alrj.v42i2.1743

(C) 2018 The Author(s)

Corresponding author: Nicole Khoury

Author contact: nkhoury@uic.edu

Article type: Research article

Article accepted: 24th October 2018

Published online: $30^{\text {th }}$ November 2018

Publisher: Institute for Women's Studies in the Arab World

Publication support provided by: Escienta

Journal ISSN: 0259-9953

Copyright: This is an Open Access article, free of all copyright, and may be freely reproduced, distributed, transmitted, modified, built upon, or otherwise used by anyone for any lawful purpose. The work is made available under the Creative Commons Attribution (CC-BY) 4.0 license. 


\title{
(Re)defining the First Mark of Development: Lebanese Feminist Discourse in Al-Raida, 1976-1985
}

\author{
Nicole Khoury
}

Department of English, University of Illinois at Chicago, Chicago, IL, USA

Respect for human dignity, recognition of the other person's rights, regardless of his appearance, color, age, sex, race or rank, is the primary requirement of civic education and the first mark of development.

Rose Ghurayyib, “1981,” 1981

\section{Abstract}

This article is a feminist history of Al-Raida, a Lebanese feminist journal launched in 1976 by the Institute for Women's Studies in the Arab World at the Lebanese American University. The article outlines the journal's role in the foundation of modern Lebanese feminist discourse, and in particular traces the dominant strand of discourse on development during the journal's first decade. By situating this strand within both dominant and local historical contexts, the article analyzes the ways in which the journal positioned arguments for development, presented research studies, and employed methodologies in order to forge solutions to Arab women's issues while maintaining international visibility through the use of normative and transnational language.

Introduction

Following the 1975 World Conference on Women in Mexico City, the United Nations (UN) formally declared 1976-1985 the Decade for Women. As a result, "almost all development agencies-international, regional, national, and UN specialized agencies-had to engage with 
the woman question. This system-wide mandate created enormous demands for information, which produced an explosion of knowledge" (Jain, 2005). Research data gathered from various organizations in developing countries increasingly revealed inequalities between men and women, as well as differences between women's issues in developed and developing countries. "Since the modernization project's concern was to 'uplift' the newly liberated nations out of their poverty and 'backwardness,' development cooperation attempted to integrate women into development as part of [the UN's] 'humanitarian' approach" (Jain 2005). However, as Jain (2005) notes, "a gap developed between development projects from the North and the research on the ground about the realities of women's lives in the South. The distances widened as the decades proceeded and the women of the South consolidated their perspective." Since the research indicated differences in women's issues, it also indicated a need to revisit the development paradigm. This period was marked by an increasing trend to question the understanding and measurement of women's work, to redefine the UN's project of development, and to further articulate women's issues in the Middle East.

Understanding how transnational feminist discourse and the circulation of ideas are appropriated by local contexts in order to resonate with social practices is an important and difficult process. As Sally Engle Merry (2006) notes, "in order for human rights ideas to be effective... they need to be translated into local terms and situated within local contexts of power and meaning. They need, in other words, to be remade in the vernacular." The question then is how local communities and cultures redefine concepts that were initially introduced within the framework of international discourse. As sites of institutionalized discourse, academic journals may allow us to trace how issues of gender in the Middle East are translated from global understandings into local contexts. Journals serve as a gatekeepers, "direct[ing] future practices by accepting some and rejecting others" (Goggin, 2000). Allowing us to trace discourse strands and narratives through historical contexts, journals document conversations while simultaneously adding to them, as they direct conversations in institutionalized contexts. This article asks how particular conversations in a particular academic journal have shaped and been shaped by its global and local contexts. 
This article offers a feminist history of Al-Raida, a Lebanese feminist journal launched in 1976 by the Institute for Women's Studies in the Arab World (IWSAW) at the Lebanese American University in Beirut. It is part of a larger study that recovers the foundations of the modern Lebanese feminist discourses articulated in the journal by employing Foucauldian critical discourse analysis to trace discourse strands or conversations that include family planning, development, politics, and narratives of the Lebanese civil war. Foucauldian critical discourse analysis (CDA) traces discourse strands through time in order to establish answers to questions such as: what is valid knowledge at a certain place and time? How does this knowledge arise, and how is it passed on? What function does it have in constituting subjects? What consequences does it have for the overall shaping and development of society? As Jäger and Maier (2001) explained, "CDA aims to disentangle the giant milling mass of discourse, to chart what is said and can be said in a given society at a given time with regard to its qualitative spectrum (What is said? How is it said?), and to uncover the techniques through which discursive limits are extended or narrowed down."

Discourse, defined by Link in Jäger and Maier (2001), is exerts power by regulating an institutionalized way of talking. Therefore, discourses do not merely reflect reality, but are also determinants of reality through, as Jäger and Maier (2001) observed, "intervening active subjects in their social contexts as co-producers and co-agents of discourses." Furthermore, CDA is critical in that it reveals the contradiction and limits in the ways statements are articulated as a given reality. Thus, a rhetorical analysis of discourse strands in Al-Raida may reveal what the women's movement in Lebanon has said and how it has said it, how they have situated articulations of their movement's purpose, which can further uncover the limits of the discourse taken up by the movement.

First, I assigned a subject description to the range of topics that appeared throughout the first ten years of the journal, from the beginning of 1976 until the end of 1985. The following general subjects emerged: family planning, development, politics, and narratives. Second, I measured the annual frequency of each topic and subtopic using the titles and/or the content of the articles. For those articles that seemed to address more than one subject, a determination was made based on the predominant language and focus of the article. Third, I charted the numerical 
values of the frequency of each discourse strand and subtopic, resulting in visual representations of the discourse strands, which provided a visual representation of the emergence of a subject focus throughout different time periods. Finally, by situating each dominant discourse strand within local historical contexts, this study explores the journal's shifting rhetorical function through various historical moments. Furthermore, this article analyzes the use of specialized language to articulate local subjects, while maintaining international visibility through the use of normative and transnational language. Tracing the dominant discourse strands during the first decade of the journal, the study analyzes how arguments are articulated and positioned, how research studies are presented, and what methodologies are employed to forge viable solutions to women's issues.

\section{A Lebanese Feminist Journal}

Al-Raida (Pioneer) is a quarterly journal published in English and Arabic by the IWSAW. The latter was established in 1973 at the Lebanese American University (formerly Beirut University College, BUC). The Ford Foundation provided initial funding for the institute. Al-Raida began publication in 1976, one year after the ending of the Lebanese civil war, and it continues publishing today on various women's issues in the Middle East. The publication is highly selective, is currently making the shift toward peer review, and is read worldwide in academic institutions, which are its main subscribers.

Al-Raida in its first decade, from 1976 to 1985, shifted from discourses about family planning in the Middle East implemented by the state for population control and modernization, to a discourse on development and a nuanced understanding of women's access to development opportunities. Lebanon during this period was undergoing modernization. As a result of the destructive civil war and the increasing lack of job opportunities for young educated professionals, many young men chose to emigrate. The high volume of emigration during this period resulted in an influx of women into the workforce, an increase in women's duties in the home and in society, and a shift in traditional Arab family structures as women became breadwinners and decision makers. Thus, women's access to employment, the value and pay of women's work, and the structure of the family were all called into question during this time, raising new issues for 
development in the Arab world and specifically Lebanon. This article explores how Al-Raida presented the issue of development, attempted to redefine it within the local context, and in doing so began to outline some of the basic problems facing women during this time, including literacy, healthcare, and paid employment.

\section{United Nations Development Projects: from Global to Local}

Rose Ghurayyib served as editor of Al-Raida from 1976 to 1985. Appointed by Julinda Abu Nasr, the first director of the IWSAW, Ghurayyib was given the freedom to make most of the editorial decisions, including what to publish in the journal (Abu Nasr interview). She began by writing most of the articles for Al-Raida, including translating articles from Arabic and French newspapers, magazines, and previously published Arab women's fiction and literary work. Her initiative to include past literary work by Arab women and biographies of female pioneers in the Middle East (such as May Ziadahi and Salwa Nassarii in the second issue in 1977) exemplified her efforts to situate Al-Raida within the international conversation and to contextualize the discourse on women's issues in Lebanon and the Middle East. Ghurayyib’s inclusionary approach rhetorically situated the publication in a valuable space within the dominant discourse on the women's liberation ${ }^{\text {iii }}$ movement in the Middle East. She sought to place the conversation within the discursive framework of Arab feminism, performing the rhetorical task of documenting the conversation while simultaneously contributing to it. Furthermore, Al-Raida made an effort to forge viable solutions to local women's issues by using transnational human rights language.

The values embedded in human rights discourse, such as individualism, autonomy, and equality, must first be revised and redefined according to local cultural values in order to resonate with local contexts. In light of the UN's discourse on development during the early 1980s, the redefinition of development in Rose Ghurayyib's editorials in Al-Raida exemplifies the journal's nuanced approach to redefining the dominant discourse on development to suit the local context. The definition of development as implemented by UN strategies was redefined to reflect developmental issues that were specific to Lebanese and Arab women. The increasing recognition of women's participation in the development process, and the increasing attention to labor laws and working conditions-including the recruitment of women into the labor force, equal work for 
equal pay, and the distinction between formal and informal labor-demonstrate Al-Raida's attempt to focus on the informal and flexible conditions of women's labor in Lebanon and other Middle Eastern countries.

Al-Raida initially began by implementing a top-down strategy to discuss women's issues in the Middle East by locating those issues from the outside, specifically from within an international framework of development that included UN organizations and women's liberation movements in the West. Ghurayyib's editorials during this period reveal her position on some of the major issues concerning women, and illustrate the influence of Western liberal feminist theory on her position concerning the Arab women's movement. While initially her position seemed to reflect a disconnect between feminist theory and local women's issues, this article will uncover some of the ways her editorials attempted to "localize" international issues, thereby disrupting the hegemonic international human rights discourse by revealing its inability to effect real change in the local context. Thus, the discourse in Al-Raida, while seeming to operate within an international UN framework, essentially disrupted the latter's discourse.

Similarly, by appropriating Western liberal feminist concerns, Ghurayyib's editorials paid attention to such concerns within a Middle Eastern context, thereby disrupting liberal feminist ideology. She located Middle Eastern women's concerns by localizing the issues of Western liberal feminism, thereby rhetorically situating Al-Raida simultaneously as an indigenous effort and as a part of the international women's movement. However, the development issues explored by the journal concerning women in the Middle East uncovered some of the limitations of the Western liberal feminist movement. Thus, Ghurayyib's editorials began to reflect a more comprehensive and robust view of the Arab women's movement, including further attention to family traditions, local customs and culture, and the development of the view that women and men in the Middle East were inevitably part of and influenced by the larger globalized structure of power.

In what follows I explore how Al-Raida incorporated the UN's development programs by initially working within a larger hegemonic international discourse on development and modernization in the Middle East. Next, I discuss how Al-Raida changed its definition of development to include a more nuanced view of women's issues in the Middle East, integrating a 
more thorough understanding of the local needs of Lebanese women. During this time, the Lebanese civil war was well underway, and Al-Raida could no longer ignore women's immediate needs. The journal's responses to the UN's thematic years also redefined the human rights discourse not only on women's basic needs but also on children, the elderly, and dis/ability within the context of the Lebanese civil war. For example, the UN's Year of Disabled Persons in 1981 resulted in one year of increased attention to dis/ability in developing countries. In 1981, AlRaida's editorials and articles on people with dis/abilities in Lebanon focused on those who were directly affected by the war, including men, women, and children. Al-Raida's turn to a more localized construction of the context of dis/ability in Lebanon's civil war marked an ability to reconceptualize international programs, and in so doing allowed Al-Raida to mediate the discourse of such international programs within the local context.

\section{Early Editorials: Research and Documentation}

Ghurayyib's first editorial, in the second issue of Al-Raida, introduced the "increasing consciousness of the important role that women can play in world-development today" ("Forward" 1977). Part of this role was to participate in the women's liberation movement; another was to participate in the increasing influence of the UN. Her editorial also introduced the IWSAW and its "effort to promote the increasing awareness of the role that women should play in the Arab World" ("Forward" 1977). Ghurayyib described the projects underway at the IWSAW, including the Basic Living Skills program and the Children's Literature Project for the Arab World, informing her reader of the future implementation of these projects. Her editorial for the third issue, titled "Importance of Documentation in the Arab World," introduced the documentation center at the IWSAW and the need for increasing research and documentation on women in the Middle East. While this topic appeared for the first time in her third editorial, it was reiterated throughout subsequent issues, and was also mentioned extensively in the conference proceedings, articles, and summaries she published in the journal (Ghurayyib, 1977).

For example, in the editorial for the sixth issue, "Research Projects on Women's Status: A Pressing Need in the Arab World," Ghurayyib (1978) began by arguing for the increasing need for documentation and statistics on Arab women for the purpose of social change: 
General information and sweeping statements are no longer compatible with the mentality and demands of our present age. It would be easy to say in a casual manner that illiteracy in the Arab World reaches high proportions, especially among women, but we cannot impress people by general, superficial statements. Only when statistics and figures tell them that the proportion of women illiterates in Arab countries reaches an average of 75$80 \%$ and that it is, in most cases, twice its proportion among men, then will they be convinced of the existence of the problem and the necessity of treating it.

As her editorial stated, the purpose of research and surveys on Arab women was to provide evidence of the need for change. This would demonstrate "the existence of bitter conflicts" and "prove our traditional family relationships based on selfish interest or parasitism need a complete revision" (Ghurayyib, 1978). Her call for research included a feminist perspective, which meant "exploring issues of feminist relevance with an awareness of difference, social power, and scientific oppression that is in service of political and social activism (Hesse-Biber, Leavy, \& Yaiser 2004)" (Miner-Rubino et al., 2007). Hesse-Biber and colleagues argued that the use of feminist methodology-which meant conducting research for rather than on women-constituted the difference between feminist and mainstream researchers. The emphasis on survey and research methods in Al-Raida, and the call for further data, included the notion of utilizing data to implement change, as Ghurayyib's editorial made clear.

The discourse on development and women's integration into development processes dominated the journal between 1980 and 1983. As such, the call for documentation and research was inextricably tied to women's integration into development. Of particular importance was the role women played in development, particularly their integration into the labor force.

\section{UN International Development Plan}

In 1963, a social security law was passed in Lebanon that required employers to provide benefits and healthcare to pregnant women. This was an "important development for the history of legal protection for working-women" (Abisaab, 2010). However, in a research survey of 10 
factories in 1979, iv Linda Lorfig and Julinda Abu Nasr found that only two of the factories implemented the social security law, "and the other eight forced their workers and employers to follow a special health plan devised to suit the employers' needs" (Abisaab 2010). Despite the social security legislation, many employers failed to follow measures for equality. Furthermore, in 1976 Lebanon signed an Arab agreement concerning workingwomen, which obligated the implementation of improved labor laws in Arab countries. "The agreement stated that every workingwoman was entitled to health insurance that must extend benefits to "her family"' (Abisaab, 2010). However, it was up to each country's government to decide how to interpret the term "family" (Abisaab, 2010).

In early issues of Al-Raida the topic of development was introduced through articles that summarized international and regional conference proceedings (see Figure 1).

\section{Dominant Discourse Strands in Al-Raida Journal from 1976-1988}

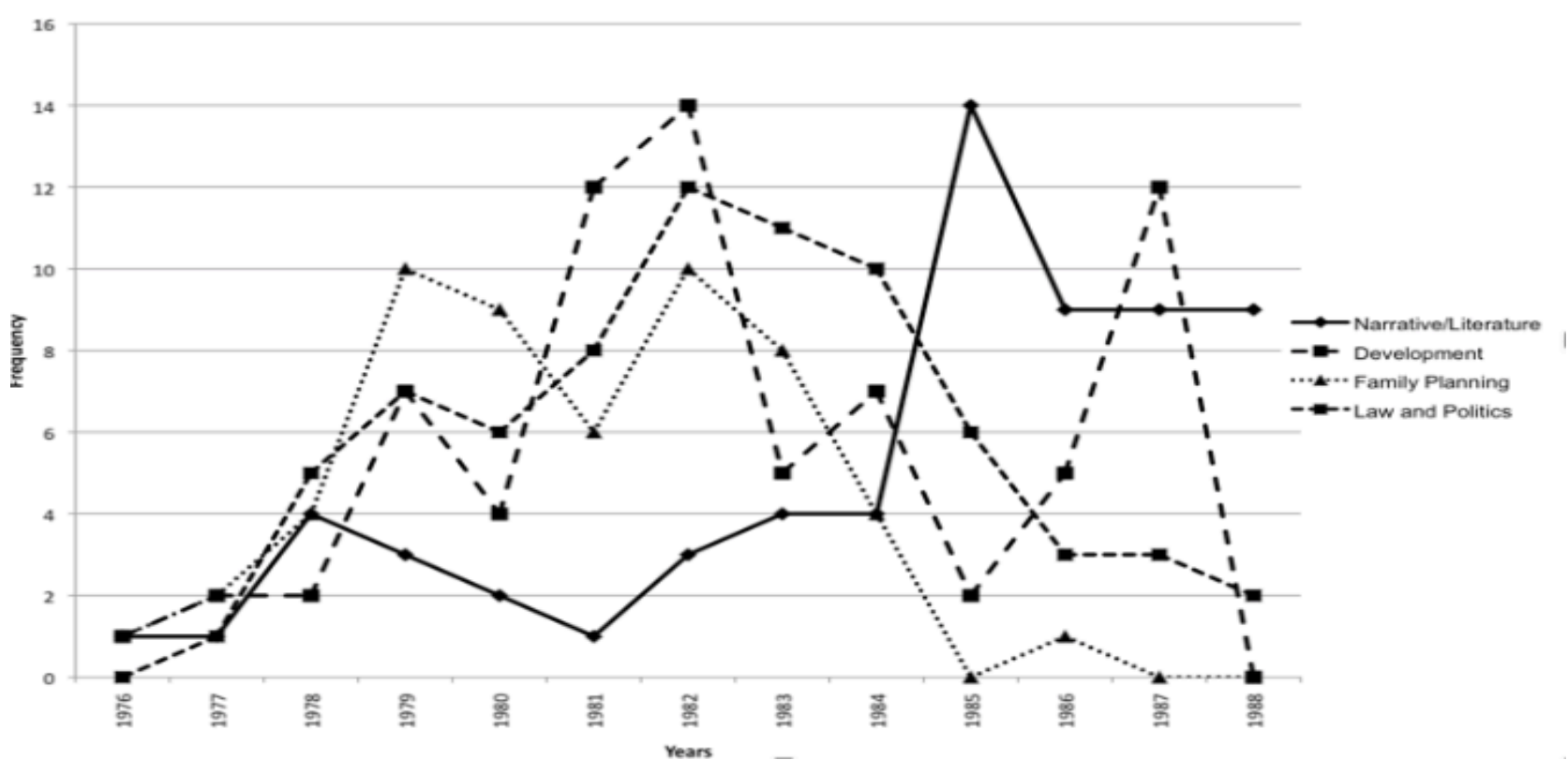

Figure 1. Dominant discourse strands in Al-Raida 1976 tp 1988, basd on the the frequency or number of articles published on a particular topic. This frequency value reflects the number of articles with titles or content material that directly mention on the the subject. 
The articles presented readers with summaries of the recommendations offered at each conference. The second issue presented recommendations concerning women's social development from the Afro-Asian Conference of March 1975 ("Recommendations of the AfroAsian Seminar", 1977). Although this conference had focused on countries and issues outside of the Middle East, the article included suggestions that were applicable to Middle Eastern countries, including women's right to work, political rights, access to education, and literacy. The same issue also summarized a presentation published in a Unicef report on July 17, 1977 by Hoda Badran, an officer for the Regional Family Welfare organization (“Unicef Activities", 1977). Badran's presentation outlined a plan to integrate women into development processes in the Eastern Mediterranean region. She highlighted the increasingly positive attitude toward women's education and integration into the development process in Arab countries. Badran's presentation also noted Unicef's continued support for Al-Azhar and the League of Arab States to develop programs for women, including "documented and classified true Islamic teaching regarding women in a series of publications" ("Unicef Activities", 1977). Furthermore, these programs included attention to "institutionalized special methodologies for working with individuals, groups and communities and for promoting women on the basis of Islamic teaching" ("Unicef Activities", 1977). While this particular article mentioned the concept of Islamic teaching, Al-Raida initially did not directly contribute to the discussion about the relationship between women and Islam. The journal did, however, publish articles that argued against the veil on the grounds that it limited women's economic participation.

The article "Middle East Regional Seminar for the Training and Education of the Rural Woman" summarized a conference held in 1978 in Cairo, Egypt, which made similar recommendations: "Since rural communities form the larger basis of social structures in a state," the article claimed, "no adequate national development is possible unless these communities recuperate their intrinsic developmental power, equally shared by both sexes." Consequently, the conference recommendations focused on constructing, developing, and implementing programs that would assist rural and bedouin women, such as creating cooperatives, developing workshops for training in dressmaking and housekeeping, and implementing "intensive information 
campaigns" to encourage rural men to accept women's involvement in decision-making ("Middle East Regional Seminar", 1978).

Similarly, a study titled "Factors Affecting the Arab Woman's Role in Rural Development," conducted by the Third Technical Periodic Conference of the Arab Rural Engineers held in Baghdad, Iraq, in March 1977, was summarized and presented in the seventh issue (1979). "Professional organizations, social groups, and administrative bodies are invited to prepare studies concerning the rural woman and emphasizing the role she should play in the developmental process" ("Factors Affecting the Arab Woman's Role", 1979). The study suggested the establishment of an Arab central statistical organization, which would provide a collaborative research environment for researchers in various disciplines on women in the Middle East. Furthermore, the recommendations included a call for the improvement of the administrative system responsible for rural frameworks. Unsuitable programs arose from a lack of training: "one major deficiency comes from inadequate training and experience among the experts and technicians of the sector, leading them to adopt educational programs borrowed from western countries whose status and problems are different from ours"v ("Factors Affecting the Arab Woman's Role", 1979). A call for further studies and attention to the role of rural women in the development process concluded the summary of this conference. A call for the elimination of illiteracy in accordance with the UN plan "which fixed the year 1985 as a deadline for the complete eradication of female illiteracy in the world" was further provided as a reminder of Arab countries' obligations ("Factors Affecting the Arab Woman's Role", 1979).

The UN regional conference for the integration of women in West Asian development held in 1978 in Amman, Jordan, was also summarized in the same issue ("Integration of the Arab Woman in Development", 1979). In a review of the conference, two documents were highlighted as integral to the process of development: "The World Plan of Action" and "The Program of Woman's Employment for Equality, Development and Peace," both adopted by the UN General Assembly, in 1975 and 1976 respectively ("Integration of the Arab Woman in Development", 1979).

\section{Redefining Women's Work}


Ghurayyib's editorial in the ninth issue, titled "Women and Work" (1979), refuted an argument made by Abdel-Rahman el Kawkabi, an Arab reformer who in 1905 blamed women for having created an unjust division of labor on the pretext of their weakness. While his words may have been meant to inspire women to work, says Ghurayyib, his argument was "a sweeping statement which may apply to a minimum number of rich women, who live in luxury and lead a lazy parasitic life" (Ghurayyib, 1979). It did not apply to rural women who "carry a full time workload in endless housekeeping tasks, requiring skill in many fields and forming a basic element in the life of the family" (Ghurayyib, 1979). Ghurayyib's editorial was an indication that the topic of women and work in Arab countries needed direct immediate attention. It also pointed to class divisions in Lebanon and their effect on women's perception of work and national development:

Women who work at the same time in and outside the home, perform a double task. If women have until now carried out these functions without any return except maintenance, this does not reduce the value of their achievement because it has a basic importance in the building of the family and of society. (Ghurayyib, 1979)

This editorial was a call for attention to women's work in rural areas and their integration into development and training programs. It was a call that the IWSAW did not hesitate to answer. Studies on the integration of women into development programs appeared in the same issue.

For example, Julinda Abu Nasr's article "Women Employment in Lebanon," condensed from a report given at the Far Eastern Conference on Career Counseling for Women in New Delhi, India, in May 1978, was the first Al-Raida publication to focus on women and work in Lebanon. The percentage of illiterate women in Lebanon, revealed Abu Nasr, stood at 53 percent in 1970. "The agricultural sector employs women at the rate of 91.7 percent," but 75.6 of those women received no salary (Abu Nasr 1979). Abu Nasr reported that women accepted jobs for which they were overqualified. "Existing discrimination regarding education opportunities and employment is mainly due to traditional attitudes of both men and women and not to law," she argued. She went on to list government programs for women, such as the Ministry of Planning's six-year plan (1972-1978) to provide boys and girls with educational opportunities "with the hope of integrating 
them in the economic and social development of the country" (Abu Nasr, 1979). She also listed non-governmental programs in the social services, such as the Lebanese Red Cross, which administered programs in schools; the Middle East Council of Churches, which encouraged literacy programs for rural women; Unicef; the Village Welfare Society, whose activities covered 22 villages; and Mouvement Social, which had established 26 medical clinics in areas such as Hermel, Baalbek, Sidon, and Beirut's prison for women (Abu Nasr, 1979). The article also reported on organizations that were attempting to address women's employment in Lebanon by implementing various social programs.

Over the next few years, Al-Raida published articles on Lebanese women that had been presented as part of the Women's Studies Lecture Series at BUC in 1979. "Development and Planning," a lecture given by Thoraya O. Sharif, defined "development planning" as a "creative process to liberate men and women and equip them with the necessary skills to be both participants and beneficiaries of development"; Sharif clearly stated this did not mean "Westernization" ("Development Planning for Women", 1980). Part of the problem of implementing development programs included the sexual division of labor: "society with its burden of traditions, stands as a handicap to women's integration in development. It should stop regarding women's work as mere decoration or assistance to the husband, and considering the success of men in terms of success of their wives," Sharif argued ("Development Planning for Women", 1980). In the same lecture series, Henry Azzam's paper on “Women, Employment and Development in the Arab World" (1980) presented some of the obstacles to women's employment in the Arab world in general. He argued that the "purdah system, which usually requires women to be veiled, is still practiced in many Arab and Moslem countries" (Azzam, 1980). This system “restricts women's appearance in public and their participation in development. Moreover, it limits any opportunity for education" (Azzam, 1980). Furthermore, the high value placed on children, the idea of safeguarding a woman's virtue, and the increase in poverty all placed limits on women's economic activity. "Parents who may be willing to educate their daughters are compelled by poor economic conditions to limit their expenditure to the education of their male children, leaving females illiterate," he argued (Azzam, 1980). Again, illiteracy and lack of access 
to educational opportunities were highlighted as major obstacles to women's participation in economic activity, but this was coupled with an increased attention to the roles of women in the family and society, and the ways these prescribed roles restricted women's economic participation.

The end of 1980 marked a shift toward publishing local conference proceedings and local research. The IWSAW's conferences on women's issues, and increasing enrollment on and attention to women's studies courses at BUC, generated an increased focus on research on women's status in Lebanon. For example, a study conducted by four BUC women's studies students on "The Effects of Wives' Employment on the Dynamics of the Lebanese Family" was published in the journal's 14th issue. This study, by Hanan Haidar, Suzan Nehmé, Doris Tchatalbochian, and Abibi Tubobanini (1980), reported findings from surveys of women's participation in household tasks, their decision-making contributions to the family, and their attitudes toward sex roles, in three cities with different economic profiles: Beirut, Jbeil, and Baalbek. The results indicated that "Lebanese working women share more in decision making than the non-working, and the operative authority structure in their family tends to be equalitarian"vi (Haidar et al., 1980). Furthermore, the study revealed, "the data on division of household tasks supported the hypothesis that women's employment outside the home gave them more opportunities to be helped by their husbands in housework" (Haidar et al., 1980). The publication of this study, in addition to other studies focused on Lebanon in the same issue, such as “Woman's Image in the Lebanese Press 1935-1975" (1980) and "What is Wrong with Our Family Traditions?" (1980), illustrates a turn toward innovative new research that contributed to the conversation on Lebanese women at local conferences organized by the IWSAW and women's studies courses at BUC, instead of relaying recommendations presented at international conferences.

The 14th issue also included two studies on the status of women in the Arab world. The first, "Traditional Family Relations in the Arab World", gave examples of the political structure in Lebanon and its relation to kinship structures. The second, "Personal Status Laws in Arab Countries," presented the resolutions of a seminar held in Beirut six years previously, in May 1974. Illiteracy and education, while still major issues affecting women, were no longer presented as 
isolated phenomena independent of cultural and social issues. Instead, they were presented as intertwined. The discourse on development began to shift, allowing further exploration of the various problems facing women, such as definitions of kinship relations in Arab society, personal status codes, and religion.

For example, the Unesco conference in Beirut in November 1980 presented research by Lebanese speakers such as Habib Zamut, regional advisor for the development of cooperatives in the International Labor Organization; Anissa Najjar, president of the Village Welfare Association in Lebanon; and Munir Bashshur, professor of education at the American University of Beirut. The speakers called on "the high authorities in the Arab world to elaborate a new code of personal status laws giving women complete equality with men" ("Unesco Conference in Beirut", 1981). "Seminar on Social Problems of the Lebanese Working Woman: A Serious Effort for Her Promotion" (1981) summarized a seminar held in Beirut a year later, in February 1981. The seminar presented recommendations for legislation in Lebanon, with a focus on maternity leave, paid study leave, social security, and changing labor laws to include rural women. While Al-Raida also published development plans and conferences held in Egypt, Kuwait, Jordan, Tunisia, and the United Arab Emirates, the focus remained on Lebanese women. A further conference paper by Henry Azzam published in 1982 reiterated the need for the government to implement changes concerning women's labor (Azzam, 1982).

Hassan Hammoud's IWSAW-funded study, "Factors Affecting the Education and Employment of Women in the Arab World," identified factors that affected the employment and education of women in Bahrain, Iraq, Jordan, Kuwait, Lebanon, Syria, and Tunisia (Hammoud 1983). While the major obstacle, according to Hammoud (1983), was illiteracy, "which ranges from $50 \%$ to $76.6 \%$ in the countries studied," the study also identified four major factors preventing women from continuing their education: lack of encouragement from parents; the unavailability of secondary schools within the area; the "modesty code," which prevented women from mingling with men in public places; and lack of motivation. Hammoud's study illustrated the increasing attention being paid to women's cultural and social status. 
In 1982 and 1983, Al-Raida presented extracts from a presentation by Huda Zurayk (1982) at the Second National Conference for Demographic Policies, organized by the Lebanon Family Planning Association in April 1982. In these two extracts, Zurayk calls for a nuanced understanding of women's work in the home and in rural economic activities. "An evaluation of women's participation in economic development," she argued, "requires the provision of accurate information about it, which is generally defective in the Arab world." The lack of statistical data illustrated how women's domestic activities and work in the home were overlooked and undervalued (Zurayk, 1982). Furthermore, "in collecting data about working women, those who do irregularvii work are often omitted; when the husband answers for his wife he often refuses to recognize her extra work in and outside the home" (Zurayk, 1982). Zurayk argued that survey questionnaires must be revised to include women who did irregular work. No analysis of women's work could obtain adequate results because of the "scarcity of studies about the nature of domestic tasks" and the "difficulty of defining and covering them" (Zurayk, 1982). She concluded by stating that the effectiveness "of national strategic policies regarding woman's work depends on the preparation of accurate informational data and the creation of a positive attitude towards it in society as a whole" (Zurayk, 1982). A shorter version of this article was reprinted in the following issue, reiterating the need for a more comprehensive understanding of women's work both inside and outside of the home, and calling again for accurate statistical data.

\section{International Observance Years}

Al-Raida rarely published thematic issues, but those that did appear are telling of the way the journal framed subtopics regarding development and women's role in society. While not every issue could be categorized as thematic, some were structured around particular subtopics, and these subtopics initially followed the UN's International Observance Years. For example, a spike in articles on dis/ability during 1980-1981 corresponded with the UN's Year of Disabled Persons (see Figure 2). However, UN Observance Years that were not specifically relevant to Lebanon or Arab women, such as International Anti-Apartheid Year (1978-1979) or the International Year of Mobilization for Sanctions Against South Africa (1983), were not used as themes for the journal. 


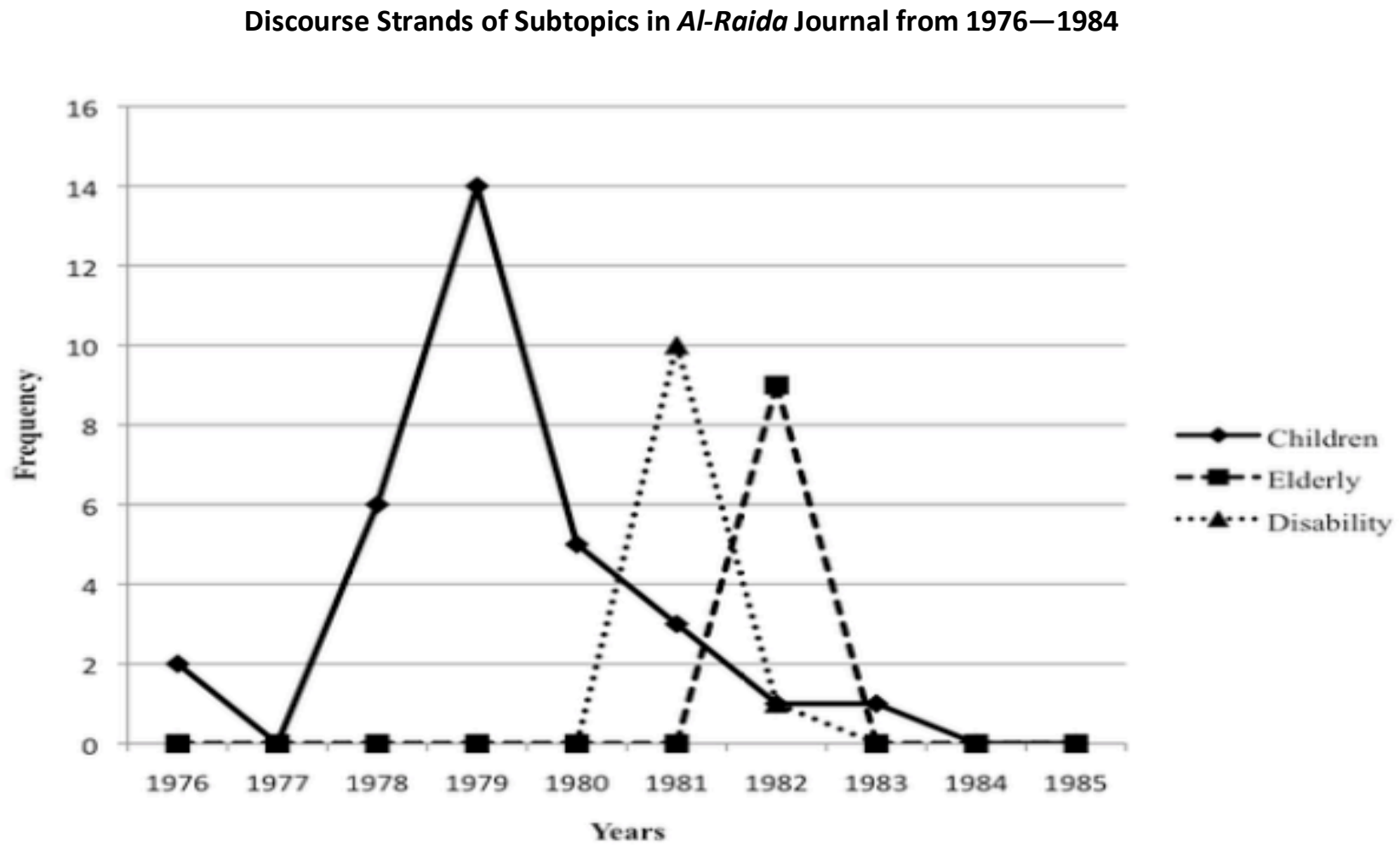

Figure 2. Discourse subtopics in Al-Raida 1976 to 1985, based on the frequency of appearance of each subtopic. The frequency value reflects the number of articles with titles or content material that directly mention the subject.

Since Lebanon was a society at war, themes relevant to the local context were chosen, such as children, disabled, and the elderly. Ghurayyib's editorials on these subtopics demonstrated her ability to contextualize issues suggested by the UN within the situation of Lebanon. Most of the thematic issues incorporated Western liberal feminist definitions of women's issues.

An analysis of journal issues such as that published during the UN's International Year of the Child in 1979 illustrates the rhetorical strategies Ghurayyib used to remain within dominant discourses while offering more local and contextualized understandings. It also demonstrates that Al-Raida's readership was not only Lebanese and Arab women, but also English-language readers that belonged to the dominant international forum on women's issues in the Middle East, namely the UN, as well as readers who could act as research funders, such as the Ford Foundation. By choosing to publish in English and remain within the dominant discourse, the journal continued to function as a means for localizing that dominant discourse, as well as informing the international 
forum about Lebanese women, and situating Lebanese and Arab women within the larger international structure.

\section{UN Observance Years, 1979 and 1982}

In the Year of the Child in 1979, the eighth issue of Al-Raida focused on international issues pertaining to children, such as the UN Declaration of the Rights of the Child and the purpose of the International Year of the Child. In her editorial, Ghurayyib stated that it was not only a woman's role in society to be a caregiver and to raise a child: it was the responsibility of the whole society. Thus, the situation in Lebanon during the civil war created a moral dilemma about raising children. Ghurayyib began her editorial by stating that millions of dollars were being spent on war all over the world. In this context, she argued, "it is vain to speak of the Children's Year in the shadow of canons and bullets. Violence like fire is spreading everywhere and threatening the world with extinction and all of us are responsible for this degradation" (Ghurayyib, 1979). She pleaded with her audience to heed her call for peace. The editorial demonstrated her disillusionment about the UN's ability to implement peace and development in Arab countries. The urgency of her editorial reflected a turbulent period when Lebanon faced a bloody civil war that claimed the lives of many people, including children. Her exasperated tone and her call for peace reflected the tone of conversation in the women's movement, where there was increased attention to the psychological effects of the war on women and children, and to attempts to rebuild society. She called on women and children to be the bearers of peace and reconciliation: "If men have created war, women and children who make more than two-thirds of the world population, should become the force of peace" (Ghurayyib, 1979). Although she incorporated the UN's International Year of the Child into her editorial, she did so within the context of the war in Lebanon, purposefully disrupting the dominant narrative and redefining the issue in a local context. Furthermore, she incorporated the UN's position of encouraging women to be active peacemakers, a position that was articulated during the Mexico City conference in 1975. The perception of women at that conference had been no longer just as victims, but "also as potential contributors to the peacemaking process" (Jain, 2005). Incorporating the language of UN, 
Ghurayyib positioned women at the center of the solution and called on them to enact nonviolence instead of passively disengaging from the conflict.

In a further example, Al-Raida's 19th issue incorporated articles on the elderly in response to the upcoming UN World Assembly on Aging. The introductory article ("Preview", 1981) presented excerpts from a summary published by the UN Office of Public Information's NonGovernmental Organizations Section on May 1, 1979. "In 1970, there were 291 million people in the world over the age of 60," the summary stated ("Preview", 1981). "This figure will increase by $100 \%$, by the year 2000, to 582 million older adults. The increase will be most pronounced in the developing world" ("Preview", 1981). In response to these statistics, Ghurayyib's editorial in the 20th issue focused on "Women and Old Age," in which she argued that women were at the center of all of the UN's international activities: in the "application of the Universal Declaration of Human Rights, adopted by the General Assembly of U.N. in 1948, it is especially woman's rights as a citizen, a daughter, a wife, a mother and a worker that should be rehabilitated because, all through the eight thousand years of patriarchal domination, most of those rights were denied to her" (Ghurayyib, 1982). The editorial went on to explain that while Arab tradition required care of the elderly within the family, little or no information had been gathered about the status of the elderly in the Arab region. Thus, while Al-Raida continued to incorporate the UN Observance Years, it did so by localizing issues and uncovering discrepancies between international definitions and goals and the local needs.

As described in this section, the journal drew on the dominant discourse to shape the local conversation. However, my analysis has also revealed that the rhetorical space where the journal operated was neither entirely located in the international forum nor exclusively tied to the local audience, but lay within both the dominant discourse and the local context simultaneously. That the journal was shaped by the dominant discourse is clearly demonstrated in its thematic issues and the language used throughout the publication. It is also clear that the journal was shaping the current conversation through its use of dominant discourses and definitions that it took from the UN forum and redeveloped for local readers and the local context. However, as the next section will elaborate, the journal not only shaped but was also shaped by the local context, including the 
redefinitions of the dominant language and the choice of articles published in response to local needs. Furthermore, the journal did not completely disarticulate from the dominant discourse: it continued to find value in incorporating UN documents and human rights language, and it continued to articulate political representation and rights for women in the Middle East. As a result, the journal occupied a discursive rhetorical space where it shaped and was shaped by both dominant and local conversations about Lebanese women.

\section{(Re)Defining Development}

By May 1983, the discourse on development encompassed attention to several factors affecting women's employment, including a nuanced understanding of women's work outside and inside the home, women's participation in agricultural work, the perception of women's roles in Arab society, women's access to education, female illiteracy rates, and the development of organizations seeking to integrate women into economic activities. The increasing attention to women's role in development culminated in editorials in two issues, numbers 24 and 25, both published in 1983. In these editorials, Ghurayyib defined the term "development." In the editorial for issue 24, titled "What Is Development?", Ghurayyib stated that the term was increasingly found in feminist literature and that there was a special emphasis on development in UN publications, including "The World Plan of Action" and "The Program for Women's Employment for Equality, Development and Peace." Referring to Canadian President of the International Development Agency, Marcel Massé's attempt to answer the question "what do we mean by development?", Ghurayyib explained: "he notes that in the early days of cooperation, development meant something tangible, like founding a new school, or erecting a dam or bridge" (Ghurayyib, 1983). But in the past 30 years, the definition had changed: "development is no longer thought of in material terms but rather as a qualitative change in the way people think, act and relate to their environment" ("What is Development?", 1983). Whereas an influx of capital had once been thought to be the answer to problems, she states, this was no longer the case. Clarifying the distinction between development and Westernization, Ghurayyib was careful to note that "another prerequisite for the success of development is an understanding of people's background, 
of their cultural heritage, which would make possible the adaptation and harmonization of the new with the old" ("What Is Development?", 1983). She also cited Massé's emphasis that "the essence of development is people." Ghurayyib explained that in "understanding other cultures, Westerners will become aware of the relativity of their own values and culture," and it was up to the citizens of developing countries to provide Westerners with "ample and accurate information about themselves and their cultural heritage" ("What Is Development?", 1983).

This shift in focus was illustrated by the selection of articles in the 24th issue in 1983. Articles no longer simply focused on development as a theme, but incorporated a more complex understanding of research on women's participation in various areas. The issue included a research study on Egyptian women and children, an article titled "Women and Science at BUC," and discussions of traditional Iranian women's coping strategies, ${ }^{i x}$ Saudi Arabian women working within an Islamic framework, ${ }^{x}$ and the revival of the veil. ${ }^{\text {xi }}$ Furthermore, "Women and Peace" by Nada Khoury (1983) summarized "women's peace activities" in Sweden, Poland, Cuba, the Philippines, and South Africa, ending with a call to prevent violence both inside and outside the home in Lebanon. The shift in methodology, from presenting research studies and documenting development organizations' recommendations to articulating a more ethnographic approach, continued to develop throughout the next couple years of the journal.

Ghurayyib's editorial on "Women's Participation in Development" (1983) in the 25th issue stated: "woman's participation in development is key to her total liberation; in order to participate in development she must be engaged in meaningful work; in order to engage in meaningful work she must be liberated and well trained." The editorial pointed to a connection made in previous issues of Al-Raida, emphasizing that women's economic participation required literacy education. Ghurayyib made this connection clear throughout the editorial: "education and work are intrinsically related; one imposes the other. Work without education has little value; education without work is sterile" (Ghurayyib, 1983). The editorial went on to delineate the connection between education, development, and women's social status: "it helps eliminate sexual discrimination, modify the concept of woman's social role and abolish the traditional division of 
labor; it also leads to the gradual elimination of the veil which forms a handicap to her outside work and her social contacts" (Ghurayyib, 1983).

Although she redefined the term "development" here, some of Ghurayyib's initial influences nevertheless remained, and she was unable to fully disarticulate from liberal terminology. She did, however, note the increasing need to localize issues and establish local organizations. For example, her editorial in the 27-28th issue, "1984, the Beginning of a New World Communication Order?" (1984), presented the trend toward "decolonizing" the news, influenced by Indian Prime Minister Indira Gandhi's address to the first Conference of Ministers of Information of Non-Aligned Countries in January 1984. Because the media encouraged a consumer mentality, she stated, it was no surprise that more women "in the Arab and Western World [were] trying to counterbalance this image by producing their own magazines, journals, radio, TV programmes and establishing their own publishing houses" (Ghurayyib, 1984). Thus she was aware that while these trends were occurring in the Arab world, Western women were also adopting them.

One of the last articles on women and development in the Middle East was published in 1984, following the IWSAW's Workshop on Arab Women in Industry, held in Ayia Napa, Cyprus, on May 21-23, 1984. The purpose of the workshop, which was financed by the Ford Foundation, was to identify relevant research topics and methodologies for Arab countries. The workshop presented a set of guidelines and recommendations that included a call for more research focused on women in societal, household and factory (industrialization) areas. The call for research methodology included longitudinal studies, interdisciplinary approaches, greater sensitivity to historical context, clearly defined research designs and methods, clear target beneficiaries of the research, and an effort to involve women wherever possible (Abu Nasr, 1984). Much of the discussion during the workshop demonstrated the need for research to make visible changes in the lives of Arab women. The call for interdisciplinary research methodology exemplified increasing attention to research that would offer a wider perspective on the role of women in the Middle East, instead of research that was limited in scope and design. It also invited researchers from various fields to participate. Furthermore, the increasing frequency of workshops and studies 
funded by the Ford Foundation through the IWSAW, and the consequent research focus on women's issues in the Middle East, demonstrated the involvement of Al-Raida and the IWSAW in establishing a collaborative research environment within a larger international framework.

For example, a couple years after stepping down as editor of Al-Raida in 1983, Ghurayyib published "Women's Integration in Development, an Imperative of Our Time" (1985), in which she presented a perspective on women's issues by linking all the major themes of the previous 10 years: tradition, education, family planning, development, financial status, age, illiteracy, etc. She began the article by stating that the rise in life expectancy for people in general imposed a "renewed concern with old age" (Ghurayyib, 1985). She claimed this was especially problematic for women, because "as whole, they are financially and socially less privileged than men" (Ghurayyib, 1985). She made connections between the various issues that plagued women at the time, and presented them as all part of a much larger social issue. Referring to Betty Friedan's research on American women, she made a similar argument that women's participation was decreasing at all levels. Her article was a call for action that gave her readers an understanding of the networks that shaped their lives and the importance of agency to implement change.

While the subtopics of the discourse strand on development in Al-Raida closely followed the UN's international activities, Ghurayyib's editorials demonstrated her ability to situate those subtopics within the context of Lebanon, and to draw attention to the problems civil society faced during the civil war. Her disillusionment about the UN's ability to keep peace in her country did not prevent her from incorporating its charters and declarations on women, children, people with dis/abilities, and the elderly, or from emphasizing the importance of those issues in war-torn Lebanon. Her editorials indicated the need to understand what all those issues had in common with the women's liberation movement: "respect for human dignity, recognition of the other person's rights, regardless of his appearance, color, age, sex, race or rank, is the primary requirement of civic education and the first mark of development" (Ghurayyib, 1981). 


\section{Local Turns in Feminist Articulations}

Ghurayyib's editorials illustrate the various shifts in the journal's discourse, from attention to international programs to implement change, to more nuanced and comprehensive understandings through the "network model" of feminist ideology, to use Rebecca Dingo's metaphor. Throughout the first 10 years of the journal, Ghurayyib's editorials disrupted the narrative of the liberated Western feminist attempting to emancipate the women of the Global South. Her editorials focused on the ways in which the UN's international programs challenged local traditions and failed to consider the values and beliefs of Middle Eastern women. Furthermore, her editorial commentaries continued to develop, reflecting a consistent ability to redefine her own understanding not only of feminism, but also of development, modernization, and the peace movement. Ghurayyib's editorials also illustrate a shift in the conversation about women's issues in Lebanon and the Middle East, from the top-down implementation of international programs to the bottom-up sharing of lived experiences, elaborating on Lebanese women's grassroots movements during the war, and working within the local cultural and traditional framework to arrive at viable solutions for issues facing women.

In realizing the limitations of the modernizing framework with respect to women's inclusion in public spheres such as the workplace, and the law's inability to directly effect social change, Al-Raida began to develop a comprehensive understanding of women in the Global South. The understanding of modernization's historical context of colonialism, exploitation, and global development, and of its restricted ability to change local women's lived realities, marked a shift in Al-Raida's discourse on women's political participation. This shift encompassed the increased valorization of women's narratives and literature during the war. In addition to its increasing publication of interviews, wartime biographies of women, and war narratives, Al-Raida's attention to women's particular situations, including women in the peace movement during the Lebanese war, redefined the dominant discourse on women in politics. The shift in the types of article 
chosen for publication, from research-based quantitative studies to the more qualitative documentation of narratives, indicated a shift in Al-Raida's rhetorical function, as well as in its perception of the kinds of studies needed for the development of a feminist movement in Lebanon. Its shift toward the valorization of women's narratives indicated Al-Raida's increasing ability to respond to the nuances of the local women's movement.

Given the diversity of women in Lebanon and the Middle East, one group cannot represent the whole, nor can any one group give more than a partial account or representation of the development of the feminist movement. "As a self-selected group, feminists differ from the majority of women in various and manifold ways" (Hawkesworth, 2006). Arab feminist positions offer an amalgamation of voices, purposes, and arguments, each representing a partial view of the movement. Rather than insisting on a unified voice, the move to valorize the plural voices in the movement, and the call to develop a comprehensive understanding of how Arab women differ, is an important strength to contest dominant discourses, including their own, which may oppress and silence marginalized groups such as Palestinian women. Unless we apply careful, historical and political analysis, the notion of "woman as an oppressed group," as Mohanty (1991) states, may set up a hierarchy among Arab feminists, similar to the hierarchy that exists between Western and Arab feminists: an oppressive relationship in which one group of women represents another. While constructing historical representations of women, it is imperative that we researchers continue to uncover the various representations of women, continue to disrupt the narrative, and continue to redefine the terms used to define us. 


\section{Notes}

' Ghurayyib, "A Study on a Woman Pioneer Writer: May Ziadeh," 3.

ii Ghurayyib, "Salwa Nassar: Lebanon," 5.

iii While the term "women's liberation" generally identifies a movement for women's liberation in a Western context, it was initially used in Al-Raida to refer to the local women's movement as well. It is in this sense that I use it here.

iv Lorfig, Irene and Julinda Abu Nasr, "A Survey of Workingwomen in the Factories of Beirut's Suburbs," 1979.

$\checkmark$ It is not clarified what the difference is in this summary.

vi It is also possible, however, that men initially held a more open-minded approach toward gender roles within the home.

vii Although no definition of "irregular" work is provided in the article itself, it can be understood as unwaged labor, seasonal labor, work inside the home (such as making products that are later sold), and labor that does not provide a steady income.

viii By Nada Khoury

ix Mary Elaine Hegland, "Traditional Iranian Women: How They Cope," 11.

× Lou'ay Nahry, "The New Saudi Woman: Modernizing in an Islamic Framework," 6-7.

xi "Revival of the Veil and Its Causes," 5.

\section{References}

Child Welfare in Lebanon. (1979). Al-Raida, 8(2), 5.

Development Planning for Women. (1980). Al-Raida, 13(3), 6.

Factors Affecting the Arab Woman's Role in Rural Development. (1979). Al-Raida, 7(2), 10.

Impact of War on Lebanese Children and Youth. (1979), Al-Raida, 8(2), 6-7.

Integration of the Arab Woman in Development Discussed at a U.N. Regional Conference. (1979). Al-Raida, $7(2), 11$.

Middle East Regional Seminar for the Training and Education of the Rural Woman. (1978). Al-Raida, 5(1), 6. Personal Status Laws in Arab Countries. (1980). Al-Raida, 14(3), 6.

Preview of the World Assembly on the Elderly. (1981). Al-Raida, 15(4), 15.

Recommendations of the Afro-Asian Seminar Regarding Women's Social Development. (1977). Al-Raida, 2(1), 8.

Revival of the Veil and Its Causes. (R. Ghurayyib, Trans.). (1983). Al-Raida, 24(6), 5.

Seminar on Social Problems of the Lebanese Working Woman: A Serious Effort for Her Promotion. (R. Ghurayyib, Trans.). (1981). Al-Raida, 17(4), 3.

Traditional Family Relations in the Arab World. (1980). Al-Raida, 14(3), 4-5.

UNESCO Conference in Beirut. (1981). Al-Raida, 15(4), 10.

UNICEF Activities for Integrating Women in Development. (1977). Al-Raida, 2(1), 11.

What is Wrong With Our Family Traditions? (1980). Al-Raida, 14(3), 3.

Woman's Image in the Lebanese Press 1935-1975. (1980). Al-Raida, 14(3), 12-13.

Abisaab, M. (2010). Militant Women of a Fragile Nation. Syracuse University Press. 
Abu Nasr, J. (1979). Impact of War on Moral Values in Lebanese Children. Al-Raida, 8(1),7.

Abu Nasr, J. (1979). Women Employment in Lebanon. Al-Raida, 9(1), 10.

Abu Nasr, J. (1984). Women in Industry. Al-Raida, 30(1), 20-21.

Abu Nasr, J. (2011, August 5). Personal interview.

Azzam, H. (1980). Women, Employment and Development in the Arab World. Al-Raida, 3(1), 7.

Burke, K. (1969). A rhetoric of motives (Vol. 178). Berkeley: University of California Press.

Dennerlein, B. (2012). Remembering violence, negotiating change: The Moroccan Equity and

Reconciliation Commission and the politics of gender. Journal of Middle East Women's

Studies, 8(1), 10-36.

Saadawi, N. (1982). A Strategy for the Integration of Arab Women in the Arab Unity Movement. Al Raida, 5(1), 9-10.

Goggin, M. D. (2000). Authoring a discipline: Scholarly journals and the post-World War II emergence of rhetoric and composition. Abingdon, Oxfordshire: Routledge.

Ghurayyib, R. (1981). 1981, the Year of the Handicapped [Editorial]. Al-Raida, 4(1), 1.

Ghurayyib, R. (1984). 1984, The Beginning of a New World Communication Order? [Editorial]. Al-Raida, 27-28 (7), 1.

Ghurayyib, R. (1977). A Study on a Woman Pioneer Writer: May Ziadeh. Al-Raida, 2(1), 3.

Ghurayyib, R. (1977). Forward [Editorial]. Al-Raida, 2(1), 1.

Ghurayyib, R. (1978). Importance of Documentation in the Arab World [Editorial]. Al-Raida, 3(1), 1.

Ghurayyib, R. (1978). Research Projects on Women's Status: A Pressing Need in the Arab World

[Editorial]. Al-Raida, 6(1), 1.

Ghurayyib, R. (1977). Salwa Nassar: Lebanon. Al-Raida, 2(1), 5.

Ghurayyib, R. (1984). "The Harem Window." Sisterhood is Global: The International Women's Movement Anthology (pp. 414-423). Ed. Robin Morgan. New York: Anchor Press.

Ghurayyib, R. (1979). The Year of the Child: The Year of Hope [Editorial]. Al-Raida, 8(2), 1.

Ghurayyib, R. (1983). What is Development? [Editorial]. Al-Raida, 24(6), 1.

Ghurayyib, R. (1982). Women and Old Age [Editorial]. Al-Raida, 20(5), 1.

Ghurayyib, R. (1979). Women and Work [Editorial]. Al-Raida, 9(2), 1.

Ghurayyib, R. (1985). Women's Integration in Development, an Imperative of Our Time. Al-Raida, 34(8), 14.

Ghurayyib, R. (1983). Women's Participation in Development [Editorial]. Al-Raida, 25(6), 1.

Haidar, H. (1980). The Effect of Wives Employment on the Dynamics of the Lebanese Family. Al-Raida, 14(4), 10-11.

Haidar, H., Nehmé, S., Tchatalbochian, D. \& Tubobanini, A. (1980). The Effects of Wives' Employment on the Dynamics of the Lebanese Family. Al-Raida, 14(3), 10-11.

Hammoud, H. (1983). Factors Affecting the Education and Employment of Women in the Arab World. AlRaida, 26(6), 10-11.

Hawkesworth, M. E. (2006). Globalization \& Feminist Activism. New York: Rowman \& Littlefield Publishers Inc.

Hegland, M. E. (1983). Traditional Iranian Women: How They Cope. Al-Raida, 24(6), 11.

Jaeger, S., \& Maier, F. (2016). Analysing discourses and dispositives: a Foucauldian approach to theory and methodology. Methods of Critical Discourse Studies, 3rd ed. London, UK: Sage Publications, 109-136. 
Jain, D. (2005). Women, development, and the UN: A sixty-year quest for equality and justice. Indiana University Press.

Khoury, N. (1983). Women and Science at BUC. Al-Raida, 24(6), 2-3.

Merry, S. E. (2006). Human rights and gender violence: Translating international law into local justice. University of Chicago Press.

Miner-Rubino, K., Epstein Jayaratne, T. \& Konik, J. (2007). “Using Survey Research as a Quantitative Method for Feminist Social Change." Handbook of Feminist Research: Theory and Praxis. Ed. Sharlene Nagy Hesse-Biber. London: Sage Publications, 199-222.

Mohanty, C. T. (1991). Under Western Eyes: Feminist Scholarship and Colonial Discourses. Third World Women and the Politics of Feminism. Eds. Chandra Talpade Mohanty, Ann Russo, and Lourdes Torres. Bloomington: Indiana University Press.

Morgan, R. (Ed.). (1996). Sisterhood is global: The international women's movement anthology. Feminist Press at CUNY.

Nahry, L. (1983). The New Saudi Woman: Modernizing in an Islamic Framework. Al-Raida, 24(6), 6-7.

Salibi, K. (1998). A House of Many Mansions: The History of Lebanon Reconsidered. Berkeley: University of California Press.

Zurayk, H. (1982). Promoting Women's Economic Activity in Lebanon and Other Arab Countries. Al-Raida, 21(5), 13. 